\title{
Reestablishing T Cell Tolerance by Antibody-Based Therapy in Type 1 Diabetes
}

\author{
Y. Maurice Morillon ${ }^{1}$ Aaron Martin ${ }^{1} \cdot$ Gregory Gojanovich $^{1} \cdot$ Bo Wang ${ }^{1}$. \\ Roland Tisch ${ }^{1,2}$
}

Received: 11 November 2014 / Accepted: 2 February 2015/Published online: 20 March 2015

(C) L. Hirszfeld Institute of Immunology and Experimental Therapy, Wroclaw, Poland 2015

\begin{abstract}
Type 1 diabetes (T1D) is an autoimmune disease in which the insulin-producing $\beta$ cells are selectively destroyed. $\beta$ cell-specific T cells are considered to be the major mediators of pathology. Accordingly, most immunotherapies tested in the clinic to date have focused on reestablishing self-tolerance within the $\mathrm{T}$ cell compartment. Monoclonal antibodies $(\mathrm{Ab})$ targeting a variety of lymphocyte surface proteins have demonstrated benefits in preclinical and clinical settings. Indeed, the use of $\mathrm{Ab}$ to target $\mathrm{T}$ cells directly or indirectly has proven to be an effective strategy to rapidly suppress $\beta$ cell autoimmunity and establish tissue-specific, long-term tolerance in rodent T1D models. In this review, we describe a number of these Ab-based immunotherapies, discuss associated immune regulatory mechanisms, and highlight results obtained in T1D clinical trials.
\end{abstract}

Keywords Autoimmunity - Immunotherapy · Immunoregulation $\cdot \mathrm{T}$ cells

Roland Tisch

rmtisch@med.unc.edu

1 Department of Microbiology and Immunology, University of North Carolina at Chapel Hill School of Medicine, Chapel Hill, NC 27599, USA

2 Lineberger Comprehensive Cancer Center, University of North Carolina at Chapel Hill School of Medicine, Chapel Hill, NC 27599, USA

\section{Introduction}

Type 1 diabetes (T1D) is characterized by the autoimmune destruction of the insulin-secreting $\beta$ cells, which reside in the pancreatic islets of Langerhans. $\beta$ cell autoimmunity is viewed as a chronic inflammatory response involving immune effector cell infiltration (i.e., insulitis) of the islets. Once initiated, the diabetogenic response may progress for a number of years until the majority of $\beta$ cell mass is destroyed or rendered nonfunctional, at which time T1D is clinically diagnosed. Various types of immune effectors such as T and B cells, and innate cells such as NK cells, macrophages, and dendritic cells (DC) contribute to $\beta$ cell autoimmunity. However, the general consensus is that both $\mathrm{CD}^{+}$and $\mathrm{CD}^{+} \mathrm{T}$ cells targeting multiple autoantigens are the critical drivers of $\beta$ cell autoimmunity. In rodent models of T1D, such as the non-obese diabetic (NOD) mouse and biobreeding rat, $\mathrm{CD} 4^{+}$and $\mathrm{CD} 8^{+} \mathrm{T}$ cells are essential for mediating efficient $\beta$ cell destruction and overt diabetes (Anderson and Bluestone 2005; Bach 1994; McDevitt and Unanue 2008). In T1D subjects, a strong genetic association with specific HLA class I and II alleles (Jahromi and Eisenbarth 2006), and an increased frequency of circulating $\beta$ cell-specific T cells provide indirect evidence that $\mathrm{T}$ cells drive human T1D (Arif et al. 2004; Kronenberg et al. 2012). Indeed, islets of cadaveric pancreases from T1D patients typically contain $\mathrm{T}$ cells, consisting mostly of $\mathrm{CD}^{+} \mathrm{T}$ cells (Coppieters et al. 2012; Mallone et al. 2007; Martinuzzi et al. 2008). Diabetic pancreases have also been observed without detectable $\mathrm{T}$ cell infiltration suggesting heterogeneity in the pathogenesis of human T1D (Arif et al. 2014; In't Veld 2014; Richardson et al. 2011; Rodriguez-Calvo et al. 2014).

The breakdown of $\beta$ cell-specific tolerance in the $\mathrm{T}$ cell compartment is complex, influenced by environmental, 
genetic, and age-dependent factors (Anderson and Bluestone 2005; Bach 1994; He et al. 2013; Todd 2010). Dysregulation of peripheral tolerance mechanisms is thought to favor the differentiation and expansion of pathogenic effector $\mathrm{T}$ cells (Teff) versus immunoregulatory $\mathrm{T}$ cells (Treg) (Tisch and Wang 2008). In NOD mice the pathogenicity of type $1 \mathrm{CD}^{+}$and $\mathrm{CD} 8^{+}$Teff infiltrating the islets is initially suppressed by Foxp3-expressing $\mathrm{CD} 4{ }^{+}$Treg $\left(\right.$Foxp $3^{+}$Treg). However, due to insufficient local levels of interleukin (IL)-2, islet resident Foxp $3^{+}$Treg survival is impaired resulting in expansion of pathogenic Teff and efficient $\beta$ cell destruction (Goudy et al. 2011; Tang et al. 2008). Notably, Foxp $3^{+}$Treg from T1D patients exhibit defects in expansion and suppressor function that are attributed to impaired IL-2 receptor (IL-2R) signaling (Garg et al. 2012; Long et al. 2010). These defects coupled with Teff that exhibit reduced sensitivity to Treg-mediated suppression in vitro also suggest aberrant peripheral tolerance in T1D subjects (Schneider et al. 2008).

Many immunotherapies in T1D clinical trials have focused on reestablishing the functional balance between Treg and Teff (Luo et al. 2010). Ideally, an immunotherapy would selectively tolerize islet infiltrating Teff, promote expansion and/or differentiation of $\beta$ cell-specific Treg to maintain islet tolerance long-term, and would leave microbial and tumor immunity intact. In the clinic, immunotherapies can be used to prevent the onset of overt diabetes in at-risk individuals, as well as rescue $\beta$ cell mass and ideally restore insulin independence in new-onset T1D subjects. The latter was formally demonstrated in early clinical studies assessing the efficacy of the immunosuppressive drug cyclosporine A (CsA) in recent-onset T1D patients (Assan et al. 1985; Bougneres et al. 1990; Canadian-European Randomized Control Trial Group 1988; Stiller et al. 1984). Depending on the time of intervention, dose and duration of CsA treatment, diabetes reversal was reported in $20-65 \%$ of patients. However, the severe side effects of CsA precluded extended treatment, and recurrent diabetes was observed once drug administration was stopped. While diabetes reversal may be unachievable for patients who have managed T1D for a number of years, protection of residual $\beta$ cell mass can still have a marked therapeutic benefit. For instance glucose control can be enhanced with reduced insulin use, thereby minimizing or delaying associated T1D complications.

There continues to be a need for immunotherapies that selectively suppress $\beta$ cell-specific $\mathrm{T}$ cell reactivity longterm in at-risk or new-onset T1D subjects. Immunotherapies employing antibodies $(\mathrm{Ab})$ have shown efficacy in the treatment of T1D. Ab-based immunotherapies can directly inhibit immunopathogenic Teff as well as modulate the expansion and function of Treg. Furthermore, once established, self-tolerance may persist long-term without subsequent treatments, which is not seen with the application of immunosuppressive drugs (e.g., CsA). For the purpose of this review we will discuss the application of different Ab-based immunotherapies, including the use of immunoglobulin (Ig) fusion proteins, to manipulate $\beta$ cell-specific $\mathrm{T}$ cell reactivity with an emphasis on strategies tested in the clinic. We will focus on $\mathrm{Ab}$ approaches that directly and indirectly impact autoreactive Teff and Treg.

\section{Ab-Based Therapies Directly Targeting T Cells}

Direct targeting of $\mathrm{T}$ cells in preclinical and clinical T1D studies have employed $\mathrm{Ab}$ specific for various molecules including: (1) the $\mathrm{T}$ cell receptor (TCR) complex (e.g., CD3, TCR $\alpha$ and $\beta$ chains), (2) co-stimulatory (e.g., CD2) and co-receptor (e.g., CD4, CD8) molecules, and (3) cytokine receptors [e.g., IL-2R (CD25), IL-7R $\alpha$ (CD127)] (Table 1). In the limited number of clinical studies assessing $\mathrm{T}$ cell-specific $\mathrm{Ab}$ in T1D, outcome is dependent on the nature of the targeted molecule(s) and the subsequent effect(s) on $\mathrm{T}$ cells (Table 1). Two general approaches have been employed: therapies that broadly target $T$ cells and most recently, strategies that target specific T cell subsets. The former embodies the "shotgun" approach, which enhances the likelihood that diseaserelevant pathogenic (and regulatory) $\mathrm{T}$ cell subsets are modulated, but also increases the potential of unwanted effects on general immune function and homeostasis. The latter approach is expected to minimize deleterious effects on general immunity, but efficacy is dependent on whether targeting specific $\mathrm{T}$ cell subsets leads to sufficiently robust tolerance.

\section{Suppressing $\beta$ Cell Autoimmunity by Broadly Targeting $\mathbf{T}$ Cells}

\section{Anti-Thymocyte Globulin Therapy}

Anti-thymocyte globulin (ATG) therapy has been used to deplete $\mathrm{T}$ cells in the transplantation arena. A polyclonal IgG cocktail, ATG exhibits reactivity to multiple antigens expressed by $\mathrm{T}$ cells as well as B cells, DC and other immune effectors (Mohty 2007). In NOD mice, treatment with ATG at a preclinical T1D stage prevents diabetes onset (Simon et al. 2008). However, only a modest effect is seen in newly diabetic NOD mice; $\sim 30 \%$ of animals receiving ATG undergo remission (Parker et al. 2009; Vargova et al. 2011). Interestingly, the effects of ATG are dependent on the activation status and subset of Ab-bound $\mathrm{T}$ cells. Naïve $\mathrm{CD} 4^{+}$and $\mathrm{CD} 8^{+} \mathrm{T}$ cells are preferentially depleted whereas memory $\mathrm{T}$ cells and Foxp $3^{+}$Treg are 


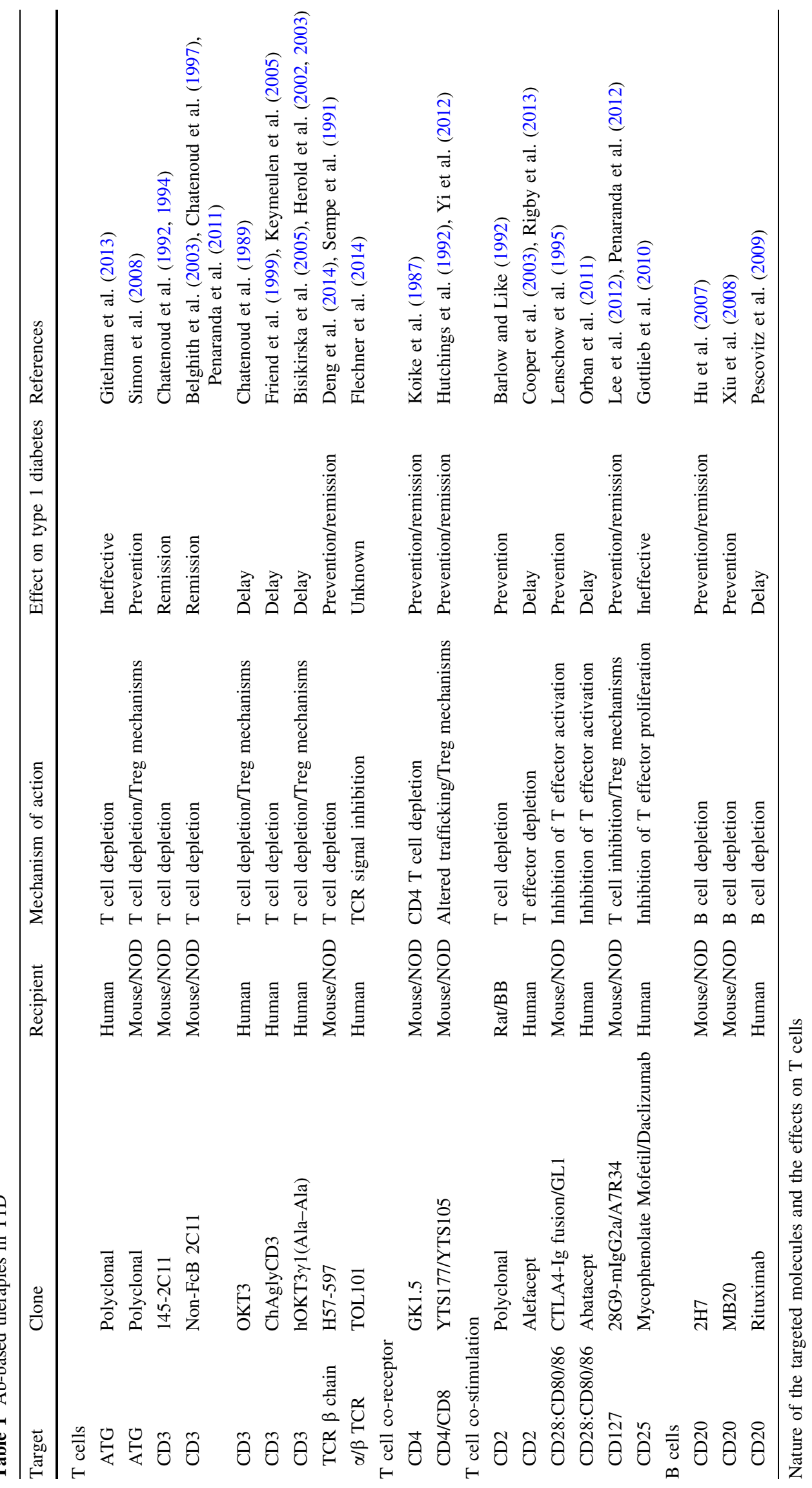


relatively resistant to the effects of ATG (Xia et al. 2012). An increase in Foxp $3^{+}$Treg coupled with the capacity of ATG to skew antigen-stimulated T cells towards protective IL-4- and IL-10-secreting Th2 and Tr1 cells, respectively, are thought to reestablish peripheral immunoregulation and suppress $\beta$ cell autoimmunity (Xia et al. 2012). The effects of ATG binding to B cells and DC are also expected to indirectly modulate $\mathrm{T}$ cell reactivity (Monti et al. 2003; Zand et al. 2005).

Recently, a 12-month phase II trial was completed assessing a short course of ATG in new-onset T1D subjects (Gitelman et al. 2013). Subjects exhibited a number of adverse events associated with acute $\mathrm{T}$ cell depletion, as well as cytokine release syndrome (CRS) due in part to activation of ATG-bound $\mathrm{T}$ cells and other immune effectors. ATG failed to rescue residual $\beta$ cell mass; levels of insulin C-peptide (which reflect endogenous insulin synthesis) were not preserved. In addition, no decrease was seen in glycated hemoglobin (HbA1c) levels or insulin use, which are additional metabolic indicators of improved $\beta$ cell function. The frequency of circulating Foxp $3^{+}$Treg was increased but not maintained over time. The failure of ATG therapy to mediate a protective effect may be due to at least two key reasons. First, elevated levels of proinflammatory cytokines induced by ATG are expected to impair $\beta$ cell survival and/or function; $\beta$ cells are sensitive to the cytotoxic effects of interferon (IFN)- $\gamma$, tumor necrosis factor (TNF)- $\alpha$ and IL-1 $\beta$ (Eizirik et al. 2009; Thomas and Kay 2000). In addition, high levels of proinflammatory cytokines may reduce Foxp $3^{+}$Treg survival and suppressor activity. Second, effector memory $\mathrm{T}$ cells are not depleted by ATG, which permits the re-activation of the diabetogenic $\mathrm{T}$ cell response. These findings suggest that generalized $\mathrm{T}$ cell depletion alone is insufficient to block ongoing $\beta$ cell autoimmunity, particularly in the context of high levels of systemic inflammation.

\section{Anti-CD3 Ab Therapy}

To date, anti-CD3 Ab therapy in the clinic has proven to be the most effective at altering the diabetogenic response, and the most thoroughly studied Ab-based approach for the treatment of T1D (Chatenoud 2010; Chatenoud et al. 2012). Preclinical studies provided strong rationale for testing anti-CD3 Ab therapy in the clinic (Chatenoud et al. 1994, 1997). A short course of anti-CD3 Ab reverses diabetes long-term in $\sim 60 \%$ of newly diabetic NOD mice (Belghith et al. 2003). Mechanistic studies in mice indicate that disease reversal is associated with two key events. The first event entails inactivation and/or removal of pathogenic Teff (Penaranda et al. 2011). Upon anti-CD3 Ab binding, pancreatic Teff are rapidly depleted via induction of apoptosis; a significant frequency (e.g., $30-50 \%$ ) of peripheral $\mathrm{T}$ cells is also deleted albeit transiently, in a dose-dependent manner (Chatenoud et al. 1994, 1997). Anti-CD3 Ab can also induce long-term anergy in CD4 ${ }^{+}$ and $\mathrm{CD}^{+} \mathrm{T}$ cells that is maintained via PD1-PDL1 interactions (Fife et al. 2006). The second event involves differentiation of $\beta$ cell-specific adaptive Foxp $3^{+}$Treg in the periphery (Belghith et al. 2003). This process is supported by transforming growth factor (TGF)- $\beta 1$, which is secreted by antigen-presenting cells (APC) in response to anti-CD3 Ab-induced apoptotic Teff (Perruche et al. 2008; You et al. 2007). In addition, natural Foxp $3^{+}$Treg are comparatively resistant to the depleting and inactivating effects of anti-CD3 Ab (Penaranda et al. 2011). The overall result is re-establishment of the functional balance between pathogenic Teff and protective Foxp $3^{+}$Treg, and suppression of $\beta$ cell autoimmunity.

Testing the clinical efficacy of anti-CD3 Ab therapy for T1D has primarily focused on two humanized anti-CD3 $\mathrm{Ab}$ : hOKT3 $\gamma 1$ (Ala-Ala) and ChAglyCD3, also known as teplizumab and otelixizumab, respectively (Bisikirska et al. 2005; Herold et al. 2002, 2005; Keymeulen et al. 2005, 2010b). Importantly the Fc regions of the respective human IgG1 molecules were mutated to limit $\mathrm{Fc}$ receptor binding to APC and NK cells. Earlier preclinical and clinical studies showed that native anti-CD3 Ab induced CRS, owing to robust activation of $\mathrm{T}$ cells, and $\mathrm{Fc}$ receptorexpressing cells following anti-CD3 Ab-mediated crosslinking (Abramowicz et al. 1989). Fc engineering of the anti-CD3 $\mathrm{Ab}$ significantly reduces these effects, although some degree of CRS is observed, especially following the first course. Regardless, a therapeutic benefit was demonstrated in phase II clinical trials assessing a short course of teplizumab or otelixizumab in recently diagnosed T1D subjects. Although reversal of diabetes was not achieved, some T1D subjects treated with teplizumab or otelixizumab showed improved C-peptide production, and reduced insulin use relative to control groups (Bisikirska et al. 2005; Herold et al. 2002, 2005; Keymeulen et al. 2005, 2010b). Nevertheless, protection was transient, lasting 2 to 4 years for teplizumab and otelixizumab, respectively (Herold et al. 2005; Keymeulen et al. 2010b). Furthermore, both $\mathrm{Ab}$ induced transient $\mathrm{T}$ cell depletion systemically, which in the case of otelixizumab was associated with recurrent Epstein-Barr virus infection in some patients (Keymeulen et al. 2010a).

The mechanism(s) involved in teplizumab- and otelixizumab-induced protection is ill-defined. The depletion of circulating $\mathrm{T}$ cells suggests a role for purging of islet Teff (Herold et al. 2013b). Observations also suggest that Treg contribute to protection. A unique subset of Foxp $3^{+} \mathrm{CD}^{+} \mathrm{T}$ cells are elevated in peripheral blood of teplizumab-treated individuals (Bisikirska et al. 2005), as are $\mathrm{CD} 4{ }^{+} \mathrm{CD} 25^{\mathrm{hi}} \mathrm{Foxp}^{+} \mathrm{T}$ cells expressing IL-10 and 
CCR6 (Waldron-Lynch et al. 2012). The latter is particularly interesting in view of results showing that in humanized mice treated with teplizumab, human $\mathrm{CD}^{+} \mathrm{T}$ cells expressing CCR6 traffic to the small intestine where IL-10 expression and a Treg-like phenotype are induced (Waldron-Lynch et al. 2012). Notably, teplizumab or otelixizumab treatment is most effective in T1D subjects exhibiting relatively elevated functional $\beta$ cell mass at the time of treatment (Herold et al. 2013a; Keymeulen et al. 2010b). This suggests that likely responders to anti-CD3 Ab therapy are those that have "less aggressive" $\beta$ cell autoimmunity and/or are treated at a relatively early stage of clinical T1D.

Despite initial promising results, recent phase III trials for teplizumab and otelixizumab in newly diagnosed T1D subjects have been underwhelming (Daifotis et al. 2013; Hagopian et al. 2013; Sherry et al. 2011). For both antiCD3 Ab, primary endpoints were not achieved. However, key caveats need to be considered when interpreting these findings. The phase III study of teplizumab used a composite primary endpoint based on insulin requirements and HbA1c levels, which were arbitrarily selected and not validated by earlier studies. Indeed, post hoc analyses using proven endpoints showed efficacy for teplizumab consistent with earlier studies (Hagopian et al. 2013; Sherry et al. 2011). In an attempt to minimize adverse events, the dose of otelixizumab was reduced 15-fold relative to earlier phase II studies (Daifotis et al. 2013), which may have limited efficacy of the treatment in the phase III trial.

In view of results achieved with anti-CD3 Ab therapy, targeting other chains of the TCR may prove to be as (or more) effective in modulating $\beta$ cell autoimmunity while exhibiting improved safety (Table 1). In NOD mice, treatment with Ab specific for the TCR $\beta$ chain (clone H57597) prevents diabetes onset and restores glycemic control if administered within one week of onset (Sempe et al. 1991). Furthermore, single dose administration of anti$\mathrm{TCR} \beta \mathrm{Ab}$ protects islet allograft models through mechanisms of selective Teff depletion and expansion of alloantigen-specific Foxp $3^{+}$Treg (Deng et al. 2014; Miyahara et al. 2012). Notably, anti-TCR $\beta$ Ab induces considerably less cytokine release by $\mathrm{T}$ cells compared to anti-CD3 Ab. In addition, since anti-TCR $\beta$ (and/or $\alpha$ ) Ab target only $\mathrm{T}$ cells that recognize peptide in the context of classical HLA molecules, the possibility of general T cellinduced immunosuppression is reduced compared to administration of anti-CD3 Ab, which also targets $\gamma \delta \mathrm{T}$ cells and NKT cells. Depending on results of a phase III trial assessing an anti-TCR $\alpha \beta$ Ab (TOL101) in renal transplantation (Flechner et al. 2014), this approach may be attractive for trials aimed at T1D and other T cell-mediated autoimmune diseases.
Targeting the CD4 and CD8 Co-Receptors: A future Approach to Reestablishing $\beta$ Cell-Specific Tolerance in the Clinic?

Recent work has shown that administration of non-depleting Ab specific for the CD4 and CD8 co-receptors is an effective strategy to selectively suppress $\beta$ cell autoimmunity long-term in NOD mice. Treatment with a short course of non-depleting anti-CD4 (YTS177) and anti-CD8 (YTS105) Ab rapidly induces remission (e.g., as soon as $72 \mathrm{~h}$ post-treatment) in the majority $(>80 \%)$ of newly diabetic NOD mice that persists indefinitely (Yi et al. 2012). Numbers and the activation status of systemic $\mathrm{T}$ cells are unaffected by co-receptor therapy. Not surprisingly both anti-CD4 and -CD8 $\mathrm{Ab}$ are required to induce efficient diabetes reversal. Purging of $\mathrm{CD}^{+}$and $\mathrm{CD}^{+} \mathrm{T}$ cells residing in the islets is a key step in the functional recovery of $\beta$ cells and the rapid induction of remission. $\mathrm{T}$ cell purging is independent of apoptosis and due instead to $\mathrm{T}$ cell egress from the pancreas. Such trafficking is likely attributed to a change in the islet microenvironment and/or the response of $\mathrm{T}$ cells to retention and/or egress cues. Strikingly, T cell purging is tissue specific; in addition to the islets, $\mathrm{T}$ cells are reduced in the draining pancreatic lymph nodes (PLN) but not in the spleen of anti-CD4/CD8 Ab-treated animals. Here it is believed that crosslinking of CD4 and CD8 has distinct effects on $\mathrm{T}$ cells in the context of ongoing inflammation versus homeostasis, thereby establishing the tissue specificity of co-receptor therapy. Long-term maintenance of remission on the other hand is attributed to increased $\beta$ cell-specific Foxp3 ${ }^{+}$Treg that selectively "reseed" the PLN and exhibit enhanced suppressor function. This pool of Foxp $3^{+}$Treg is expected to suppress activation and differentiation of pathogenic Teff, reflected by the lack of insulitis in remission NOD mice (Yi et al. 2012). Consistent with the tissue-specific effects of co-receptor therapy, immunity to foreign antigens is unperturbed in remission NOD mice ( $\mathrm{Yi}$ et al. 2012). Relative to antiCD3 and other Ab-based therapies, the use of non-depleting co-receptor-specific $\mathrm{Ab}$ has important advantages including: (1) accelerated kinetics of remission induction, likely reflecting the distinct mechanisms in $\mathrm{T}$ cell tolerance and purging, and (2) the lack of systemic $\mathrm{T}$ cell activation and depletion, thereby minimizing deleterious effects on normal immune function and homeostasis.

Clinical studies have been limited to testing non-depleting Ab specific for human CD4. Therapeutic benefit was reported in patients with psoriasis (Philipp et al. 2006), and an ongoing phase II trial (NCT0148-1493) is testing a non-depleting anti-CD4 Ab in rheumatoid arthritis patients. Currently, there is no bona fide non-depleting $\mathrm{Ab}$ specific for human CD8. The robust tissue-specific effects seen in 
preclinical work, however, provide rationale for further development and testing of non-depleting anti-CD4 and $\mathrm{CD} 8 \mathrm{Ab}$ for the treatment of T1D in the clinic.

\section{Suppressing $\beta$ Cell Autoimmunity by Targeting Specific T Cell Subsets}

Using $A b$ to selectively target $T$ cells driving and/or regulating autoimmunity would be the ideal approach to treat disease. A conundrum, however, is identifying the appropriate molecules for the relevant $\mathrm{T}$ cell subsets. To validate this approach, basic investigations were carried out in which Teff were selectively targeted using a panel of $\mathrm{Ab}$ specific for CD44 (Weiss et al. 2000), a molecule that interacts with extracellular matrix proteins (specifically hyaluronan) and is preferentially expressed by activated $\mathrm{T}$ cells (Baaten et al. 2010; Huet et al. 1989). Anti-CD44 Ab administration significantly reduces insulitis and T1D development in a $\mathrm{T}$ cell transfer model without altering other $\mathrm{T}$ cell responses (Weiss et al. 2000). With this in mind, $\mathrm{CD} 2$ has garnered recent interest for the treatment of T1D. $\mathrm{CD} 2$ functions as a co-stimulatory and adhesion molecule expressed by $\mathrm{T}$ and NK cells. CD2 binds LFA-3 (CD58) expressed by APC, and engagement or blocking of this interaction by $\mathrm{Ab}$ influences $\mathrm{T}$ cell activation, proliferation, anergy, or apoptosis. Importantly, CD2 is upregulated on activated and memory T cells (Bockenstedt et al. 1988; Green et al. 2000). The latter has been exploited to treat psoriasis in the clinic by applying a humanized fusion protein consisting of the extracellular CD2-binding domain of LFA-3 linked to the Fc region of human IgG1 (LFA3-Ig; Alefacept) (Ellis et al. 2001). Efficacy of Alefacept in psoriasis patients correlates with selective depletion of circulating effector memory $\mathrm{CD} 4^{+}$and $\mathrm{CD}^{+}{ }^{+}$cells while the naïve $\mathrm{T}$ cell pool remains largely intact (Cooper et al. 2003; Ellis et al. 2001).

A 12-month phase II trial was recently completed in which new-onset T1D subjects received two 12-week courses of alefacept (Rigby et al. 2013). The primary endpoint, preservation of C-peptide relative to placebo controls, was not achieved. However, a number of secondary endpoints were met in the alefacept-treated subjects suggesting a modicum of therapeutic benefit. Insulin requirements and the frequency of hypoglycemic events were reduced, and the drug was well tolerated. Analogous to earlier clinical findings, effector memory $\mathrm{T}$ cells were reduced in the alefacept-treated subjects. In addition Foxp $3^{+}$Treg were unaffected suggesting a shift in the balance between pathogenic versus immunoregulatory $\mathrm{T}$ cells. These findings provide support for further work testing alefacept, and developing $\mathrm{Ab}$ and/or other drugs to target CD2 for the treatment of T1D.

\section{Manipulating Diabetogenic T Cells Indirectly by Ab-Based Therapy}

Ab-based strategies have been employed in preclinical and clinical studies to indirectly block pathogenic $\mathrm{T}$ cells and suppress $\beta$ cell autoimmunity. These approaches have focused on professional APC, including B cells, macrophages, and DC. APC deliver critical signals needed for $\mathrm{T}$ cell activation, expansion, and effector cell differentiation by: (1) presenting peptide-MHC complexes (signal 1), (2) expressing co-stimulatory molecules (signal 2), and (3) secreting cytokines (signal 3). A recent study demonstrated that blocking APC-mediated "signal 1" via Ab specific for an insulin $\mathrm{B} 9-23$ peptide-IA ${ }^{\mathrm{g} 7}$ complex alters $\beta$ cell autoimmunity in NOD mice (Zhang et al. 2014). Insulin-specific $\mathrm{CD}^{+}{ }^{+}$and $\mathrm{CD} 8^{+}$) $\mathrm{T}$ cells play a key role in the diabetogenic response of NOD mice. Ab blocking of the insulin peptide-MHC class II complex in NOD mice is most effective at preventing the onset of diabetes when administered at early versus late preclinical T1D. Multiple $\beta$ cell autoantigens and epitopes are recognized as the diabetogenic response progresses, so selectively blocking insulinspecific $\mathrm{CD}^{+} \mathrm{T}$ cell priming would be expected to have only a limited effect at later T1D stages. To date, two approaches targeting APC have been tested in the clinic to treat T1D with some degree of success; namely co-stimulatory molecule blockade and B cell depletion.

\section{Co-stimulatory Molecule Blockade}

$\mathrm{T}$ cells generally become fully activated and proliferate upon TCR binding of peptide-MHC complexes (signal 1), coupled with signals transduced upon engagement of costimulatory molecules expressed by APC (signal 2). Depending on context, $\mathrm{T}$ cells receiving only signal 1 become anergic, undergo apoptosis, or differentiate into a regulatory subset (Chen and Flies 2013). Binding of CD28 expressed by naïve T cells to CD80 or CD86 on the surface of APC has provided the paradigm for the two signal model, which initially has been exploited in the clinic for inducing transplantation tolerance (Ford et al. 2014; Suntharalingam et al. 2006).

Preclinical studies in NOD mice showed that blockade of co-stimulatory molecules expressed by APC alters $\beta$ cell-specific T cell reactivity (Herold et al. 1997; Lenschow et al. 1995). However, efficacy is dependent on a number of parameters including the identity of the co-stimulatory molecule that is targeted, subsequent effects on particular T cell subsets, and the stage of $\beta$ cell autoimmunity at which therapy is initiated. For instance, treatment of NOD mice with a CTLA4-Ig fusion protein that binds to and blocks CD80 and CD86, or Ab specific for CD86 prevents the 
onset of diabetes albeit with no marked effect on the frequency of insulitis. In contrast, anti-CD80 Ab therapy exacerbates $\beta$ cell autoimmunity in NOD mice. Furthermore, the tolerogenic effect is only induced when CTLA4Ig and anti-CD86 $\mathrm{Ab}$ are applied at early but not late preclinical T1D. This temporal effect may be due to inefficient priming of select $\beta$ cell-specific clonotypes of naïve $\mathrm{CD}^{+}{ }^{+}$and $\mathrm{CD}^{+}{ }^{+} \mathrm{T}$ cells needed to efficiently drive later stages of the diabetogenic response. At late preclinical T1D, however, the impact of CD80/CD86 blockade may be reduced since the pancreatic infiltrate consists mostly of established Teff, which have only limited dependence on CD28 signaling (Tang et al. 2003). Notably, Foxp $3^{+}$Treg are also decreased by CD80/CD86 blockade due to the lack of CD28 signaling required for survival and effector function. Foxp $3^{+}$Treg are expected to play a more prominent role in achieving and maintaining tolerance under the stringent conditions encountered at later stages of $\beta$ cell autoimmunity.

Treatment of recent-onset T1D subjects for two years with a humanized CTLA4-Ig chimeric protein (abatacept) in a phase II trial results in transient efficacy with minimal adverse effects (Orban et al. 2011). C-peptide is increased throughout the 2-year period in abatacept-treated subjects, with a marked delay in C-peptide reduction seen for the initial 10 months of therapy. After this time, however, the rate of loss of $\beta$ cell function parallels that of the placebo group. Insulin use is also decreased but only for the first 12 months of abatacept therapy. Preservation of $\beta$ cell function following abatacept therapy correlates with increased circulating naïve $\mathrm{CD} 4^{+} \mathrm{T}$ cells, and a concomitant reduction in central memory $\mathrm{CD} 4^{+} \mathrm{T}$ cells and $\mathrm{FOXP}^{+-}$ Treg relative to the placebo group (Orban et al. 2014). A stable naïve $\mathrm{CD}^{+}{ }^{+} \mathrm{T}$ cell pool, which serves as a source of diabetogenic Teff, is consistent with blockade of $\mathrm{T}$ cell activation. Interestingly, abatacept inhibits transmigration of central memory $\mathrm{CD} 4^{+} \mathrm{T}$ cells across CD86-expressing microvascular endothelial cells in vitro (Lozanoska-Ochser et al. 2008). Based on this observation it was suggested that the decrease in circulating central memory $\mathrm{CD} 4^{+} \mathrm{T}$ cells in the abatacept group is due to altered trafficking properties, possibly reflecting retention of these $\mathrm{T}$ cells in the lymph nodes (Lozanoska-Ochser et al. 2008). Notably, CD28 signals have recently been shown to regulate trafficking of murine autoreactive $\mathrm{T}$ cells into target tissues (Jain et al. 2013). These findings suggest that abatacept-induced efficacy is in part achieved by delaying expansion of the pool of diabetogenic Teff. The decrease in Foxp $3^{+}$Treg induced by abatacept further reflects the role for $\mathrm{CD} 28$ signaling in Foxp $3^{+}$Treg survival and maintenance. Importantly, failure to establish an expanded or enhanced Foxp $3^{+}$Treg pool likely hinders the duration and potency of the tolerogenic effect mediated by abatacept. Furthermore, targeting co- stimulatory molecules that regulate Teff and/or memory $\mathrm{T}$ cells (e.g., CD40L, 41BBL, OX40L, CD30L, CD70) (Chen and Flies 2013) may prove to be more effective at blocking $\beta$ cell autoimmunity at late preclinical or clinical stages of T1D. Although insulin independence is an unlikely outcome of this approach, disease progression may be halted or slowed by targeting accessory signaling molecules.

\section{B Cell Depletion}

Evidence that B cells play a critical role in T1D comes from studies in which $\beta$ cell autoimmunity and overt diabetes are prevented in genetically manipulated NOD mice deficient in B cells (Serreze et al. 1996). Although a strong predictive marker for the development of overt diabetes in both mice and at-risk individuals, $\beta$ cell- and islet-specific autoantibodies are thought to have only limited pathogenicity (Holz et al. 2000; Martin et al. 2001). The consensus is that B cells serve primarily as APC directing autoantigen presentation via $\beta$ cell-specific $B$ cell receptors (Serreze et al. 1998; Silveira et al. 2004; Tian et al. 2006). Immunotherapies targeting $\mathrm{B}$ cells have proven to be effective at suppressing $\beta$ cell autoimmunity in NOD mice (Hu et al. 2007; Xiu et al. 2008). Transient depletion of B cells via anti-CD20 Ab therapy at preclinical stages of T1D prevents the onset of overt diabetes in NOD mice (Xiu et al. 2008). Protection correlates with decreased T cell infiltration of the islets, believed in part due to reduced $\mathrm{CD}^{+}{ }^{+}$and $\mathrm{CD}^{+}{ }^{+} \mathrm{T}$ cell activation in the PLN. In a second study, anti-CD20 Ab-mediated B cell depletion was reported to reverse diabetes in a small percentage $(\sim 30 \%)$ of new-onset NOD mice expressing a human CD20 transgene (Hu et al. 2007). A role for Foxp $3^{+}$Treg is suggested by a $\sim$ twofold increase in remission NOD mice. Here, restricting the pool of APC to DC and macrophages may favor the expansion and/or induction of Foxp $3^{+}$Treg and/or adaptive Treg. Interestingly, a subset of B cells with suppressor activity is detected after B cell reconstitution (Xiang et al. 2012), which may also contribute to $\beta$ cell tolerance induced by anti-CD20 Ab therapy.

A phase II trial was carried out testing an anti-CD20 Ab (rituximab) in new-onset T1D patients. Subjects received four weekly injections of rituximab and were then monitored for 12 months (Pescovitz et al. 2009, 2014). Adverse events of limited severity are mostly seen after the first infusion of $\mathrm{Ab}$, and no increase in infections is detected in rituximab-treated subjects likely reflecting preservation of memory B cells. Circulating CD $20^{+} \mathrm{B}$ cells are rapidly depleted via cell- and complement-mediated cell lysis, and by 12 months levels return to $\sim 70 \%$ of baseline values. Efficacy of rituximab, albeit transient, is indicated by a significant delay in C-peptide loss, and reduced $\mathrm{HbA} 1 \mathrm{c}$ levels and insulin usage. Surprisingly, responders to 
rituximab exhibit an increased frequency of $\mathrm{CD} 4^{+}$and $\mathrm{CD} 8^{+} \mathrm{T}$ cells specific for a panel of $\beta$ cell autoantigens (Herold et al. 2011). The elevated $\beta$ cell-specific reactivity is selective, since no difference is seen in $\mathrm{T}$ cell responses to control antigens. The phenotype of these $\beta$ cell-specific $\mathrm{T}$ cells is undefined but may represent an expanded pool of adaptive Treg. Indeed, an increase in Foxp $3^{+}$Treg numbers is also detected within the first 10 weeks of therapy (Herold et al. 2011). An additional study shows that rituximabinduced B cell depletion has a marked effect on follicular helper T cells (Tfh) in T1D subjects (Xu et al. 2013). Tfh are potent regulators of $\mathrm{B}$ cell expansion and differentiation in lymphoid germinal centers mediated in part via IL-21 secretion (Nurieva et al. 2008; Vogelzang et al. 2008). The increased frequency of Tfh and elevated levels of serum IL-21 seen in T1D subjects are reduced following rituximab treatment (Xu et al. 2013). Together these clinical findings support the notion that Ab-based targeting of B cells can impact autoreactive $T$ cell reactivity and T1D progression. The overall approach may be improved by employing various B cell-depleting agents, such as Ab or Ig recombinants specific for different $B$ cell growth factors (e.g., BAFF, APRIL) (Marino et al. 2014; Zekavat et al. 2008) to target distinct $B$ cell subsets and/or promote immunoregulatory $\mathrm{B}$ cells.

\section{Combinatorial-Based Immunotherapies: The Next Step?}

The lack of robust and durable $\beta$ cell-specific tolerance and protection induced in the clinic by Ab-based or other "mono"-immunotherapies, has led to the idea that efficacy can be enhanced by combining different strategies. The aim is to develop combinatorial therapies that are synergistic and drive robust, long-term tissue-specific tolerance. An important benefit expected from such synergy is that dose and treatment intervals for respective therapeutics will be reduced thereby improving safety.

A study by the von Herrath group provided proof of principle that a combination of approaches can synergize to effectively suppress $\beta$ cell autoimmunity (Bresson et al. 2006). Recent-onset diabetic NOD mice were given sub-optimal doses of anti-CD3 $\mathrm{F}(\mathrm{ab})_{2}$ coupled with intranasal administration of proinsulin. Diabetes reversal and the frequency of proinsulin-specific Foxp $3^{+}$Treg and adaptive Treg are significantly increased by combining the two therapies versus either alone. Anti-CD3 F(ab') purging of pathogenic Teff and subsequent quenching of ongoing inflammation is thought to establish a milieu favorable for the induction and expansion of proinsulinspecific Treg. This increased Treg pool then maintains $\beta$ cell-specific tolerance under relatively less stringent conditions (i.e., reduced Teff numbers). Synergy has also been achieved by combining anti-CD3 Ab with cellbased therapy (Baas et al. 2014). The frequency and duration of islet allograft survival are increased in mice treated with anti-CD3 $\mathrm{F}\left(\mathrm{ab}^{\prime}\right)_{2}$ plus tolerogenic DC. Islet allograft tolerance is mediated by expanded alloantigen-specific Foxp $3^{+}$Treg. A recent study demonstrated that co-treatment with anti-CD20 Ab and orally administered anti-CD3 $\mathrm{Ab}$ increases diabetes prevention and remission in NOD mice expressing human CD20 (Hu et al. 2013). Protection correlates with increased Foxp ${ }^{+}$Treg exhibiting enhanced suppressor activity, and IL-10-secreting adaptive Treg. Coupling anti-CD3 Ab therapy with IL- $1 \beta$ blockade is another example of synergy being achieved to effectively suppress $\beta$ cell autoimmunity (Ablamunits et al. 2012). As noted earlier, $\beta$ cells are sensitive to the cytotoxic effects of IL-1 $\beta$ secreted by islet innate effectors. The combination of anti-IL-1 $\beta \mathrm{Ab}$ and anti-CD3 $\left.\mathrm{F}(\mathrm{ab})^{\prime}\right)_{2}$ enhances diabetes reversal in NOD mice by an increase in both Treg and anti-inflammatory APC. It is noteworthy that a recent phase II trial showed that treatment with either anti-IL-1 $\beta \mathrm{Ab}$ (canakinumab) or an IL-1 receptor antagonist (anakinra) fails to preserve $\beta$ cell function in recent-onset T1D subjects (Moran et al. 2013).

A combinatorial approach may also complement deficiencies associated with a given immunotherapy. Low-dose IL-2 therapy has been reported to selectively increase Foxp $3^{+}$Treg and suppress graft versus host disease in the clinic (Koreth et al. 2011). Accordingly, low-dose IL-2 may protect Foxp $3^{+}$Treg from the negative effects of costimulatory molecule blockade and, therefore, prolong protection in recent-onset T1D subjects treated with abatacept, for example. Low-dose IL-2 or IL-2-Ab complexes may serve as "adjuvants" to increase Foxp $3^{+}$Treg numbers, survival and/or function and in turn enhance the efficacy of various Ab-based strategies (e.g., anti-CD3 Ab, anti-CD20, alefacept).

Improved preservation of C-peptide production may be accomplished by not only targeting $\mathrm{T}$ cells and other immune effectors, but also by directly modulating $\beta$ cell survival, function and/or replication. For instance, efficacy of anti-CD3 Ab therapy to reverse diabetes in new-onset NOD mice is improved by glucagon-like peptide 1 coadministration, which increases recovery of $\beta$ cell function and insulin secretion (Sherry et al. 2007). Interestingly, remission induced in NOD mice treated with non-depleting anti-CD4 and -CD8 Ab is partly attributed to islet APC production of TGF- $\beta 1$, which is thought to directly enhance $\beta$ cell replication and insulin secretion (Yi et al. 2012). 


\section{Concluding Remarks}

Clinical findings support the notion that progression of T1D can be altered via Ab-based immunotherapies that either directly or indirectly target $\mathrm{T}$ cells. However, the efficacy seen in the clinic has only been transient, indicating that more robust strategies are needed. An evergrowing list of targets has been explored in the various rodent models of T1D, including TCR and associated signaling molecules, co-stimulatory molecules, adhesion molecules, and cytokine and chemokine receptors. Specific Teff subsets have been targeted using both lytic and nondepleting approaches. Most of these $\mathrm{Ab}$ are effective in preventing disease progression while only a few reliably reverse hyperglycemia. Despite this extensive knowledge base, clinical efforts often do not reflect the level of scientific understanding in the arenas of rodent diabetes or human immunology. Trials have featured $\mathrm{Ab}$ that target $\mathrm{T}$ cells with the lowest level of precision (e.g., ATG), and the greatest risk of activation-associated adverse effects (e.g., anti-CD3 Ab). Because safer and more effective candidates than anti-CD3 Ab and ATG have been identified in animal studies, anti- $\mathrm{T}$ cell $\mathrm{Ab}$ remain a strategy deserving of clinical research efforts. Such efforts could be confounded by the fact that the diabetogenic response in humans is heterogeneous, possibly reflecting distinct "subsets" of T1D. It is, therefore, likely that combinatorial immunotherapies, targeting multiple effector cells and disease pathways will be required to treat T1D effectively. The challenge, however, is to identify the appropriate combination of monotherapies that promote potent synergy and long-term suppression of $\beta$ cell autoimmunity. Advancement of T1D biomarker knowledge is paramount, with the understanding that biomarker patterns may differ from case to case and that different $\mathrm{Ab}$ will have distinct effects. As a side point, immunotherapies that generally block the production of proinflammatory cytokines (IFN- $\gamma$, TNF- $\alpha$, IL$1 \beta$ ), starting from the first dose onward, while promoting anti-inflammatory/tissue repair cues hold particular promise. The key to reversing islet autoimmunity likely involves rapid elimination of the inflammatory mediators associated with autoimmunity and in response to broadly lytic $\mathrm{Ab}$, as such molecules have toxic effects on the pancreas. Cessation of autoimmunity while promoting islet repair remains the main strategic goal. Results from clinical studies of $\mathrm{Ab}$-based therapies targeting $\mathrm{T}$ cells provide for the first time, a foundation that can be exploited to improve T1D immunotherapy.

Acknowledgments This work was supported by grants from the National Institutes of Health (1R01DK100256-01; R. Tisch) and the Juvenile Diabetes Research Foundation (A. Martin).
Conflict of Interest The authors have no conflict of interest.

\section{References}

Ablamunits V, Henegariu O, Hansen JB et al (2012) Synergistic reversal of type 1 diabetes in NOD mice with anti-CD3 and interleukin-1 blockade: evidence of improved immune regulation. Diabetes 61:145-154

Abramowicz D, Schandene L, Goldman M et al (1989) Release of tumor necrosis factor, interleukin-2, and gamma-interferon in serum after injection of OKT3 monoclonal antibody in kidney transplant recipients. Transplantation 47:606-608

Anderson MS, Bluestone JA (2005) The NOD mouse: a model of immune dysregulation. Annu Rev Immunol 23:447-485

Arif S, Tree TI, Astill TP et al (2004) Autoreactive T cell responses show proinflammatory polarization in diabetes but a regulatory phenotype in health. J Clin Invest 113:451-463

Arif S, Leete P, Nguyen V et al (2014) Blood and islet phenotypes indicate immunological heterogeneity in type 1 diabetes. Diabetes 63:3835-3845

Assan R, Debray-Sachs M, Laborie C et al (1985) Metabolic and immunological effects of cyclosporin in recently diagnosed type 1 diabetes mellitus. Lancet 1:67-71

Baas MC, Kuhn C, Valette F et al (2014) Combining autologous dendritic cell therapy with CD3 antibodies promotes regulatory $\mathrm{T}$ cells and permanent islet allograft acceptance. J Immunol 193:4696-4703

Baaten BJ, Li CR, Deiro MF et al (2010) CD44 regulates survival and memory development in Th1 cells. Immunity 32:104-115

Bach JF (1994) Insulin-dependent diabetes mellitus as an autoimmune disease. Endocr Rev 15:516-542

Barlow AK, Like AA (1992) Anti-CD2 monoclonal antibodies prevent spontaneous and adoptive transfer of diabetes in the BB/ Wor rat. Am J Pathol 141:1043-1051

Belghith M, Bluestone JA, Barriot S et al (2003) TGF-beta-dependent mechanisms mediate restoration of self-tolerance induced by antibodies to CD3 in overt autoimmune diabetes. Nat Med 9:1202-1208

Bisikirska B, Colgan J, Luban J et al (2005) TCR stimulation with modified anti-CD3 $\mathrm{mAb}$ expands $\mathrm{CD} 8+\mathrm{T}$ cell population and induces CD8+ CD25+ Tregs. J Clin Invest 115:2904-2913

Bockenstedt LK, Goldsmith MA, Dustin M et al (1988) The CD2 ligand LFA-3 activates T cells but depends on the expression and function of the antigen receptor. J Immunol 141:1904-1911

Bougneres PF, Landais P, Boisson C et al (1990) Limited duration of remission of insulin dependency in children with recent overt type 1 diabetes treated with low-dose cyclosporin. Diabetes 39:1264-1272

Bresson D, Togher L, Rodrigo E et al (2006) Anti-CD3 and nasal proinsulin combination therapy enhances remission from recentonset autoimmune diabetes by inducing Tregs. J Clin Invest 116:1371-1381

Canadian-European Randomized Control Trial Group (1988) Cyclosporin-induced remission of IDDM after early intervention. Association of $1 \mathrm{yr}$ of cyclosporin treatment with enhanced insulin secretion. Diabetes 37:1574-1582

Chatenoud L (2010) Immune therapy for type 1 diabetes mellituswhat is unique about anti-CD3 antibodies? Nat Rev Endocrinol 6:149-157

Chatenoud L, Ferran C, Bach JF (1989) In-vivo anti-CD3 treatment of autoimmune patients. Lancet 2:164 
Chatenoud L, Thervet E, Primo J et al (1992) Remission of established disease in diabetic NOD mice induced by anti-CD3 monoclonal antibody. CR Acad Sci III 315:225-228

Chatenoud L, Thervet E, Primo J et al (1994) Anti-CD3 antibody induces long-term remission of overt autoimmunity in nonobese diabetic mice. Proc Natl Acad Sci USA 91:123-127

Chatenoud L, Primo J, Bach JF (1997) CD3 antibody-induced dominant self tolerance in overtly diabetic NOD mice. J Immunol 158:2947-2954

Chatenoud L, Warncke K, Ziegler AG (2012) Clinical immunologic interventions for the treatment of type 1 diabetes. Cold Spring Harb Perspect Med 2 (pii: a007716)

Chen L, Flies DB (2013) Molecular mechanisms of T cell costimulation and co-inhibition. Nat Rev Immunol 13:227-242

Cooper JC, Morgan G, Harding S et al (2003) Alefacept selectively promotes NK cell-mediated deletion of CD45R0+ human $\mathrm{T}$ cells. Eur J Immunol 33:666-675

Coppieters KT, Dotta F, Amirian N et al (2012) Demonstration of islet-autoreactive CD8 T cells in insulitic lesions from recent onset and long-term type 1 diabetes patients. J Exp Med 209:51-60

Daifotis AG, Koenig S, Chatenoud L et al (2013) Anti-CD3 clinical trials in type 1 diabetes mellitus. Clin Immunol 149:268-278

Deng R, Khattar M, Xie A et al (2014) Anti-TCR mAb induces peripheral tolerance to alloantigens and delays islet allograft rejection in autoimmune diabetic NOD mice. Transplantation 97:1216-1224

Eizirik DL, Colli ML, Ortis F (2009) The role of inflammation in insulitis and beta-cell loss in type 1 diabetes. Nat Rev Endocrinol 5:219-226

Ellis CN, Krueger GG, Alefacept Clinical Study G (2001) Treatment of chronic plaque psoriasis by selective targeting of memory effector T lymphocytes. N Engl J Med 345:248-255

Fife BT, Guleria I, Gubbels Bupp M et al (2006) Insulin-induced remission in new-onset NOD mice is maintained by the PD-1PD-L1 pathway. J Exp Med 203:2737-2747

Flechner SM, Mulgoankar S, Melton LB et al (2014) First-in-human study of the safety and efficacy of TOL101 induction to prevent kidney transplant rejection. Am J Transplant 14:1346-1355

Ford ML, Adams AB, Pearson TC (2014) Targeting co-stimulatory pathways: transplantation and autoimmunity. Nat Rev Nephrol 10:14-24

Friend PJ, Hale G, Chatenoud L et al (1999) Phase I study of an engineered aglycosylated humanized CD3 antibody in renal transplant rejection. Transplantation 68:1632-1637

Garg G, Tyler JR, Yang JH et al (2012) Type 1 diabetes-associated IL2RA variation lowers IL-2 signaling and contributes to diminished CD4+ CD25+ regulatory T cell function. J Immunol 188:4644-4653

Gitelman SE, Gottlieb PA, Rigby MR et al (2013) Antithymocyte globulin treatment for patients with recent-onset type 1 diabetes: 12-month results of a randomised, placebo-controlled, phase 2 trial. Lancet Diabetes Endocrinol 1:306-316

Gottlieb PA, Quinlan S, Krause-Steinrauf H et al (2010) Failure to preserve beta-cell function with mycophenolate mofetil and daclizumab combined therapy in patients with new-onset type 1 diabetes. Diabetes Care 33:826-832

Goudy KS, Johnson MC, Garland A et al (2011) Reduced IL-2 expression in NOD mice leads to a temporal increase in CD62 $\mathrm{L}^{\text {lo }}$ FoxP3 + CD4 + T cells with limited suppressor activity. Eur J Immunol 41:1480-1490

Green JM, Karpitskiy V, Kimzey SL et al (2000) Coordinate regulation of $\mathrm{T}$ cell activation by $\mathrm{CD} 2$ and $\mathrm{CD} 28$. $\mathrm{J}$ Immunol 164:3591-3595

Hagopian W, Ferry RJ Jr, Sherry N et al (2013) Teplizumab preserves $\mathrm{C}$-peptide in recent-onset type 1 diabetes: two-year results from the randomized, placebo-controlled Protege trial. Diabetes 62:3901-3908

He Q, Morillon YM 2nd, Spidale NA et al (2013) Thymic development of autoreactive T cells in NOD mice is regulated in an age-dependent manner. J Immunol 191:5858-5866

Herold KC, Vezys V, Koons A et al (1997) CD28/B7 costimulation regulates autoimmune diabetes induced with multiple low doses of streptozotocin. J Immunol 158:984-991

Herold KC, Hagopian W, Auger JA et al (2002) Anti-CD3 monoclonal antibody in new-onset type 1 diabetes mellitus. N Engl J Med 346:1692-1698

Herold KC, Burton JB, Francois F et al (2003) Activation of human T cells by FcR nonbinding anti-CD3 mAb, hOKT3gamma1(AlaAla). J Clin Invest 111:409-418

Herold KC, Gitelman SE, Masharani U et al (2005) A single course of anti-CD3 monoclonal antibody hOKT3gamma1(Ala-Ala) results in improvement in C-peptide responses and clinical parameters for at least 2 years after onset of type 1 diabetes. Diabetes 54:1763-1769

Herold KC, Pescovitz MD, McGee P et al (2011) Increased T cell proliferative responses to islet antigens identify clinical responders to anti-CD20 monoclonal antibody (rituximab) therapy in type 1 diabetes. J Immunol 187:1998-2005

Herold KC, Gitelman SE, Ehlers MR et al (2013a) Teplizumab (anti$\mathrm{CD} 3 \mathrm{mAb}$ ) treatment preserves $\mathrm{C}$-peptide responses in patients with new-onset type 1 diabetes in a randomized controlled trial: metabolic and immunologic features at baseline identify a subgroup of responders. Diabetes 62:3766-3774

Herold KC, Gitelman SE, Willi SM et al (2013b) Teplizumab treatment may improve C-peptide responses in participants with type 1 diabetes after the new-onset period: a randomised controlled trial. Diabetologia 56:391-400

Holz A, Dyrberg T, Hagopian W et al (2000) Neither B lymphocytes nor antibodies directed against self antigens of the islets of Langerhans are required for development of virus-induced autoimmune diabetes. J Immunol 165:5945-5953

Hu CY, Rodriguez-Pinto D, Du W et al (2007) Treatment with CD20specific antibody prevents and reverses autoimmune diabetes in mice. J Clin Invest 117:3857-3867

Hu C, Ding H, Zhang X et al (2013) Combination treatment with antiCD20 and oral anti-CD3 prevents and reverses autoimmune diabetes. Diabetes 62:2849-2858

Huet S, Groux H, Caillou B et al (1989) CD44 contributes to T cell activation. J Immunol 143:798-801

Hutchings P, O'Reilly L, Parish NM et al (1992) The use of a nondepleting anti-CD4 monoclonal antibody to re-establish tolerance to beta cells in NOD mice. Eur J Immunol 22:1913-1918

In't Veld P (2014) Insulitis in human type 1 diabetes: a comparison between patients and animal models. Semin Immunopathol 36:569-579

Jahromi MM, Eisenbarth GS (2006) Genetic determinants of type 1 diabetes across populations. Ann N Y Acad Sci 1079:289-299

Jain N, Miu B, Jiang JK et al (2013) CD28 and ITK signals regulate autoreactive T cell trafficking. Nat Med 19:1632-1637

Keymeulen B, Vandemeulebroucke E, Ziegler AG et al (2005) Insulin needs after CD3-antibody therapy in new-onset type 1 diabetes. N Engl J Med 352:2598-2608

Keymeulen B, Candon S, Fafi-Kremer S et al (2010a) Transient Epstein-Barr virus reactivation in CD3 monoclonal antibodytreated patients. Blood 115:1145-1155

Keymeulen B, Walter M, Mathieu C et al (2010b) Four-year metabolic outcome of a randomised controlled CD3-antibody trial in recent-onset type 1 diabetic patients depends on their age and baseline residual beta cell mass. Diabetologia 53:614-623

Koike T, Itoh Y, Ishii T et al (1987) Preventive effect of monoclonal anti-L3T4 antibody on development of diabetes in NOD mice. Diabetes 36:539-541 
Koreth J, Matsuoka K, Kim HT et al (2011) Interleukin-2 and regulatory $\mathrm{T}$ cells in graft-versus-host disease. $\mathrm{N}$ Engl $\mathrm{J}$ Med 365:2055-2066

Kronenberg D, Knight RR, Estorninho M et al (2012) Circulating preproinsulin signal peptide-specific CD8 $\mathrm{T}$ cells restricted by the susceptibility molecule HLA-A24 are expanded at onset of type 1 diabetes and kill beta-cells. Diabetes 61:1752-1759

Lee LF, Logronio K, Tu GH et al (2012) Anti-IL-7 receptor-alpha reverses established type 1 diabetes in nonobese diabetic mice by modulating effector T-cell function. Proc Natl Acad Sci USA 109:12674-12679

Lenschow DJ, Ho SC, Sattar H et al (1995) Differential effects of anti-B7-1 and anti-B7-2 monoclonal antibody treatment on the development of diabetes in the nonobese diabetic mouse. J Exp Med 181:1145-1155

Long SA, Cerosaletti K, Bollyky PL et al (2010) Defects in IL-2R signaling contribute to diminished maintenance of FOXP3 expression in $\mathrm{CD} 4(+) \mathrm{CD} 25(+)$ regulatory $\mathrm{T}$-cells of type 1 diabetic subjects. Diabetes 59:407-415

Lozanoska-Ochser B, Klein NJ, Huang GC et al (2008) Expression of CD86 on human islet endothelial cells facilitates T cell adhesion and migration. J Immunol 181:6109-6116

Luo X, Herold KC, Miller SD (2010) Immunotherapy of type 1 diabetes: where are we and where should we be going? Immunity 32:488-499

Mallone R, Martinuzzi E, Blancou P et al (2007) CD8+ T-cell responses identify beta-cell autoimmunity in human type 1 diabetes. Diabetes 56:613-621

Marino E, Walters SN, Villanueva JE et al (2014) BAFF regulates activation of self-reactive $\mathrm{T}$ cells through B-cell dependent mechanisms and mediates protection in NOD mice. Eur $\mathbf{J}$ Immunol 44:983-993

Martin S, Wolf-Eichbaum D, Duinkerken G et al (2001) Development of type 1 diabetes despite severe hereditary B-lymphocyte deficiency. N Engl J Med 345:1036-1040

Martinuzzi E, Novelli G, Scotto M et al (2008) The frequency and immunodominance of islet-specific $\mathrm{CD} 8+\mathrm{T}$-cell responses change after type 1 diabetes diagnosis and treatment. Diabetes 57:1312-1320

McDevitt HO, Unanue ER (2008) Autoimmune diabetes mellitusmuch progress, but many challenges. Adv Immunol 100:1-12

Miyahara Y, Khattar M, Schroder PM et al (2012) Anti-TCRbeta $\mathrm{mAb}$ induces long-term allograft survival by reducing antigenreactive $\mathrm{T}$ cells and sparing regulatory $\mathrm{T}$ cells. Am $\mathrm{J}$ Transplant 12:1409-1418

Mohty M (2007) Mechanisms of action of antithymocyte globulin: T-cell depletion and beyond. Leukemia 21:1387-1394

Monti P, Allavena P, Di Carlo V et al (2003) Effects of antilymphocytes and anti-thymocytes globulin on human dendritic cells. Int Immunopharmacol 3:189-196

Moran A, Bundy B, Becker DJ et al (2013) Interleukin-1 antagonism in type 1 diabetes of recent onset: two multicentre, randomised, double-blind, placebo-controlled trials. Lancet 381:1905-1915

Nurieva RI, Chung Y, Hwang D et al (2008) Generation of T follicular helper cells is mediated by interleukin- 21 but independent of $\mathrm{T}$ helper 1,2 , or 17 cell lineages. Immunity 29:138-149

Orban T, Bundy B, Becker DJ et al (2011) Co-stimulation modulation with abatacept in patients with recent-onset type 1 diabetes: a randomised, double-blind, placebo-controlled trial. Lancet 378:412-419

Orban T, Beam CA, Xu P et al (2014) Reduction in CD4 central memory $\mathrm{T}$-cell subset in costimulation modulator abatacepttreated patients with recent-onset type 1 diabetes is associated with slower C-peptide decline. Diabetes 63:3449-3457
Parker MJ, Xue S, Alexander JJ et al (2009) Immune depletion with cellular mobilization imparts immunoregulation and reverses autoimmune diabetes in nonobese diabetic mice. Diabetes 58:2277-2284

Penaranda C, Tang Q, Bluestone JA (2011) Anti-CD3 therapy promotes tolerance by selectively depleting pathogenic cells while preserving regulatory T cells. J Immunol 187:2015-2022

Penaranda C, Kuswanto W, Hofmann J et al (2012) IL-7 receptor blockade reverses autoimmune diabetes by promoting inhibition of effector/memory $\mathrm{T}$ cells. Proc Natl Acad Sci USA 109:12668-12673

Perruche S, Zhang P, Liu Y et al (2008) CD3-specific antibodyinduced immune tolerance involves transforming growth factorbeta from phagocytes digesting apoptotic $\mathrm{T}$ cells. Nat Med 14:528-535

Pescovitz MD, Greenbaum CJ, Krause-Steinrauf H et al (2009) Rituximab, B-lymphocyte depletion, and preservation of betacell function. N Engl J Med 361:2143-2152

Pescovitz MD, Greenbaum CJ, Bundy B et al (2014) B-lymphocyte depletion with rituximab and beta-cell function: two-year results. Diabetes Care 37:453-459

Philipp S, Wolk K, Kreutzer S et al (2006) The evaluation of psoriasis therapy with biologics leads to a revision of the current view of the pathogenesis of this disorder. Expert Opin Ther Targets $10: 817-831$

Richardson SJ, Willcox A, Bone AJ et al (2011) Immunopathology of the human pancreas in type-I diabetes. Semin Immunopathol 33:9-21

Rigby MR, DiMeglio LA, Rendell MS et al (2013) Targeting of memory $\mathrm{T}$ cells with alefacept in new-onset type 1 diabetes (T1DAL study): 12 month results of a randomised, double-blind, placebo-controlled phase 2 trial. Lancet Diabetes Endocrinol 1:284-294

Rodriguez-Calvo T, Ekwall O, Amirian N et al (2014) Increased immune cell infiltration of the exocrine pancreas: a possible contribution to the pathogenesis of type 1 diabetes. Diabetes 63:3880-3890

Schneider A, Rieck M, Sanda S et al (2008) The effector T cells of diabetic subjects are resistant to regulation via CD4+ FOXP3+ regulatory T cells. J Immunol 181:7350-7355

Sempe P, Bedossa P, Richard MF et al (1991) Anti-alpha/beta T cell receptor monoclonal antibody provides an efficient therapy for autoimmune diabetes in nonobese diabetic (NOD) mice. Eur $\mathrm{J}$ Immunol 21:1163-1169

Serreze DV, Chapman HD, Varnum DS et al (1996) B lymphocytes are essential for the initiation of $\mathrm{T}$ cell-mediated autoimmune diabetes: analysis of a new "speed congenic" stock of NOD. Ig mu null mice. J Exp Med 184:2049-2053

Serreze DV, Fleming SA, Chapman HD et al (1998) B lymphocytes are critical antigen-presenting cells for the initiation of $\mathrm{T}$ cellmediated autoimmune diabetes in nonobese diabetic mice. J Immunol 161:3912-3918

Sherry NA, Chen W, Kushner JA et al (2007) Exendin-4 improves reversal of diabetes in NOD mice treated with anti-CD3 monoclonal antibody by enhancing recovery of beta-cells. Endocrinology 148:5136-5144

Sherry N, Hagopian W, Ludvigsson J et al (2011) Teplizumab for treatment of type 1 diabetes (Protege study): 1-year results from a randomised, placebo-controlled trial. Lancet 378:487-497

Silveira PA, Dombrowsky J, Johnson E et al (2004) B cell selection defects underlie the development of diabetogenic APCs in nonobese diabetic mice. J Immunol 172:5086-5094

Simon G, Parker M, Ramiya V et al (2008) Murine antithymocyte globulin therapy alters disease progression in NOD mice by a time-dependent induction of immunoregulation. Diabetes 57:405-414 
Stiller CR, Dupre J, Gent M et al (1984) Effects of cyclosporine immunosuppression in insulin-dependent diabetes mellitus of recent onset. Science 223:1362-1367

Suntharalingam G, Perry MR, Ward S et al (2006) Cytokine storm in a phase 1 trial of the anti-CD28 monoclonal antibody TGN1412. N Engl J Med 355:1018-1028

Tang Q, Henriksen KJ, Boden EK et al (2003) Cutting edge: CD28 controls peripheral homeostasis of $\mathrm{CD} 4+\mathrm{CD} 25+$ regulatory $\mathrm{T}$ cells. J Immunol 171:3348-3352

Tang Q, Adams JY, Penaranda C et al (2008) Central role of defective interleukin-2 production in the triggering of islet autoimmune destruction. Immunity 28:687-697

Thomas HE, Kay TW (2000) Beta cell destruction in the development of autoimmune diabetes in the non-obese diabetic (NOD) mouse. Diabetes Metab Res Rev 16:251-261

Tian J, Zekzer D, Lu Y et al (2006) B cells are crucial for determinant spreading of $\mathrm{T}$ cell autoimmunity among beta cell antigens in diabetes-prone nonobese diabetic mice. $\mathrm{J}$ Immunol 176:2654-2661

Tisch R, Wang B (2008) Dysrulation of T cell peripheral tolerance in type 1 diabetes. Adv Immunol 100:125-149

Todd JA (2010) Etiology of type 1 diabetes. Immunity 32:457-467

Vargova L, Zacharovova K, Dovolilova E et al (2011) Immunoregulatory effect of anti-thymocyte globulin monotherapy on peripheral lymphoid tissues of non-obese diabetic mice. Transplant Proc 43:3277-3280

Vogelzang A, McGuire HM, Yu D et al (2008) A fundamental role for interleukin-21 in the generation of $\mathrm{T}$ follicular helper cells. Immunity 29:127-137

Waldron-Lynch F, Henegariu O, Deng S et al (2012) Teplizumab induces human gut-tropic regulatory cells in humanized mice and patients. Sci Transl Med 4:118ra12

Weiss L, Slavin S, Reich S et al (2000) Induction of resistance to diabetes in non-obese diabetic mice by targeting CD44 with a specific monoclonal antibody. Proc Natl Acad Sci USA 97:285-290

Xia CQ, Chernatynskaya AV, Wasserfall CH et al (2012) Antithymocyte globulin (ATG) differentially depletes naive and memory $\mathrm{T}$ cells and permits memory-type regulatory $\mathrm{T}$ cells in nonobese diabetic mice. BMC Immunol 13:70

Xiang Y, Peng J, Tai N et al (2012) The dual effects of B cell depletion on antigen-specific $\mathrm{T}$ cells in BDC2.5NOD mice. J Immunol 188:4747-4758

Xiu Y, Wong CP, Bouaziz JD et al (2008) B lymphocyte depletion by CD20 monoclonal antibody prevents diabetes in nonobese diabetic mice despite isotype-specific differences in $\mathrm{Fc}$ gamma $\mathrm{R}$ effector functions. J Immunol 180:2863-2875

Xu X, Shi Y, Cai Y et al (2013) Inhibition of increased circulating Tfh cell by anti-CD20 monoclonal antibody in patients with type 1 diabetes. PLoS ONE 8:e79858

Yi Z, Diz R, Martin AJ et al (2012) Long-term remission of diabetes in NOD mice is induced by nondepleting anti-CD4 and anti-CD8 antibodies. Diabetes 61:2871-2880

You S, Leforban B, Garcia C et al (2007) Adaptive TGF-betadependent regulatory $\mathrm{T}$ cells control autoimmune diabetes and are a privileged target of anti-CD3 antibody treatment. Proc Natl Acad Sci USA 104:6335-6340

Zand MS, Vo T, Huggins J et al (2005) Polyclonal rabbit antithymocyte globulin triggers B-cell and plasma cell apoptosis by multiple pathways. Transplantation 79:1507-1515

Zekavat G, Rostami SY, Badkerhanian A et al (2008) In vivo BLyS/ BAFF neutralization ameliorates islet-directed autoimmunity in nonobese diabetic mice. J Immunol 181:8133-8144

Zhang L, Crawford F, Yu L et al (2014) Monoclonal antibody blocking the recognition of an insulin peptide-MHC complex modulates type 1 diabetes. Proc Natl Acad Sci USA 111:2656-2661 